\title{
Trosbegrebet hos Slavoj Žižek
}

\author{
MADS PETER KARLSEN
}

ENGLISH ABSTRACT: The aim of this article is to provide a systematic presentation of Slavoj Žižek's reflections on belief and hereby to indicate his relevance for a philosophy of religion. The article begins with a brief introduction to Žižek's basic philosophical concern and a theological contextualization of his thinking from the perspective of this concern. This is followed by an exposition of his concept of belief. The starting point of this exposition is Freud's reflections on fetishism and disavowal that form the background for Žižek's analysis of belief in modern secular society and as structural conditions of the human consciousness. Subsequently, the article presents Žižek's reflections on belief as reflective in terms 'displaced belief' in 'the other who is supposed to believe'. It is demonstrated here how Žižek operates with a distinction between an 'imaginary' belief that is structured like the fetishistic disavowal and a 'symbolic' unconscious belief in belief as such. The final section of the article sheds light on Žižek's view of atheism and his introduction of a third form of 'atheistic belief', while considering whether this kind of belief belongs to the register of the 'real'.

DANSK RESUME: Hensigten med denne artikel er at give en systematisk fremstilling af Slavoj Žižeks overvejelser over tro for herved at tematisere hans religionsfilosofiske relevans. Der indledes med en kort introduktion til Žižeks grundlæggende filosofiske anliggende og en teologisk kontekstualisering af hans tænkning ud fra dette anliggende. Derefter udfoldes fremstillingen af trosbegrebet. Udgangspunktet tages $i$ Freuds betragtninger over fetichisme og fornægtelse, der danner baggrunden for Žižeks analyser af tro i det moderne sekulære samfund og som strukturelt vilkår ved den menneskelige bevidsthed. Derefter præsenteres Žižeks overvejelser over refleksiv tro som 'forskudt tro' på 'den anden, der formodes at tro'. Det demonstreres her, hoordan Žižek opererer med et skel mellem en 'imaginær' tro, der er struktureret som den fetichistiske fornægtelse og en 'symbolsk' forudgående, ubevidst tro på selve det at tro. Til sidst $i$ artiklen belyses Žižeks opfattelse af ateistisme og hans introduktion af en tredje form for 'ateistisk tro', og det overvejes om denne form for tro kan siges at høre til $i$ det reelles register.

KEYWORDS: Slavoj Žižek; belief; faith; fetishism; atheism; the Real; the Other. 


\section{Indledning}

Denne artikel er et forsøg på at give en systematisk fremstilling af den slovenske filosof, psykoanalytiker og kulturkritiker Slavoj Žižeks talrige, men noget spredte overvejelser over tro for herved at tematisere et centralt aspekt af hans religionsfilosofiske relevans. En grundlæggende udfordring for et sådant forsøg er Žižeks særegne filosofiske stil og fremstillingsform.

I en vis forstand er den største udfordring, en læser af Žižeks bøger står over for, hverken den krævende tekniske terminologi fra filosofien og psykoanalysen eller de mange indforståede referencer til samtidens populærkultur og politiske debat, som disse bøger er fyldt med, men en tænke- og skrivestil, der konsekvent trodser konventionerne. Žižek forstår utvivlsomt sig selv som filosof, og hans bøger behandler da også i høj grad filosofiske emner, men de ligner ikke de bøger, man sædvanligvis karakteriserer som filosofibøger. De indeholder masser af referencer til og citater af filosoffer, men der er alligevel hverken tale om filosofihistorie eller systematiske behandlinger af enkelte filosofiske problemer, temaer eller forfatterskaber i streng forstand. Žižeks bøger er fyldt med analyser og diskussioner af eksempler som er hentet fra filosofien, men også fra psykoanalyse, film, populærlitteratur, kulturteori og politik. Disse eksempler er ofte placeret i en rækkefølge, der forekommer ret tilfældig. Nogle gange bruges eksemplerne til at illustrere, eksemplificere og konkretisere filosofiske pointer og argumenter, mens de andre gange analyseres og diskuteres i deres egen ret ved hjælp af bl.a. filosofiske begreber. Det er svært at finde noget, der minder om egentlige teser i Žižeks bøger, og deres argumentation udvikles ofte gennem umiddelbart usammenhængende spring fra eksempel til eksempel snarere end gennem et stringent, fremadskridende ræsonnement. Derudover rummer de altid en lang række gentagelser: Den samme vittighed, den samme filmreference, det samme citat, reproduceres i mange af bøgerne i en ny kontekst, således at man til tider kommer i tvivl om, det er den samme tekst, man læser igen (og igen). Alle disse forhold gør, at Zizeks tekster er besværlige at arbejde med, og har betydet, at store del af den akademiske verden har haft svært ved at tage ham helt alvorligt. På den ene side er det i sammenligning med visse andre filosoffer ikke så svært at læse hans tekster og endda ofte fornøjeligt. På den anden side er teksterne utrolig svære at få hånd om: Hvad var det egentlig han sagde og mente? Hvordan præcist udfoldede argumentation sig? Havde han egentlig belæg for den fortolkning han gav? I hvilken anden sammenhæng er det nu, at han har skrevet det samme?

Man bør imidlertid ikke lade sig narre af Žižeks stil. Der er et anliggende og endda et anliggende, som er forholdsvist konstant gennem hele forfatterskabet, ligesom der er en række tilbagevendende grundtemaer, som dukker op i de fleste af hans bøger. Men stilen betyder, at man ikke uden videre kan pege på ét sted, en bestemt bog fx, og sige 'her behandler Žižek dette eller hint', for der er som sagt altid også andet på spil i hans fremstilling. At give en systematisk præsentation af et særligt problem, et begreb, eller en bestemt tematik hos Žižek, betyder således ikke alene, at man er nødt til at springe fra værk til værk, fra tekst til tekst, for derved at forsøge at sammenstykke et helhedsbillede, men også, at man ikke kan undgå at 
gøre en vis vold mod Žižeks stil. Siden sin (engelsksprogede) debutbog The Sublime Object of Ideology fra 1989 har Žižek ved flere lejligheder - seneste i sin bog fra 2012 om Hegel - peget på de følgende tre omdrejningspunkter for sin tænkning: hegeliansk dialektik, lacaniansk psykoanalyse og marxistisk ideologikritik. Allerede i den første bog udstak han med afsæt i disse tre inspirationskilder rammerne for det filosofiske projekt, som med visse småjusteringer har været hans hovedanlæggende lige siden. Hans grundlæggende filosofiske og teoretiske ambition er som han påpeger i debutbogen at reaktualisere Hegels dialektik og at revidere den marxistiske ideologikritik, begge dele gennem en lacaniansk genlæsning, der herved samtidig demonstrerer psykoanalysens frugtbarhed som en 'kortsluttende' læsestrategi (Žižek 1989, 7; 1992, 2). I takt med forfatterskabets udvikling er en ekstra dimension blevet accentueret, nemlig ambitionen om at udarbejde en teori om subjektet gennem sammentænkningen af den tyske idealismes begreb om subjektivitet som 'selvrelateret negativitet' og det freudianske-lacanianske begreb om 'dødsdriften' (Žižek 2004, 61). Det skal endvidere nævnes, at Žižek også har søgt at demonstrere, at der kan drages en række etisk-politiske konsekvenser af dette teoretiske projekt. Først og fremmest har han i forlængelse af Lacan forsøgt at udstikke rammerne for en politik og en etik, der svarer til den lacanske psykoanalyses idéer om, at analysanden skal 'traversere sin urfantasi' og 'identificere sig med sit symptom'. Et centralt anliggende har i den forbindelse været at udarbejde en teori om etisk-politisk engagement centreret om Lacans begreb om Handlingen ( $\left.l^{\prime} a c t e\right)$ forstået som en grundløs intervention, der suspenderer og potentielt omstrukturerer samfundets grundlæggende symbolske orden (se Sharpe \& Boucher 2010, 165-193).

Der har fra begyndelsen været religionsfilosofiske ansatser i Žižeks arbejde i form af temaer som offer, lidelse og tro, og i form af referencer til Paulus, Pascal og Kierkegaard. Disse ansatser har imidlertid med tiden udviklet sig til en mere eksplicit refleksion over især den jødisk-kristne tradition, men også buddhisme og islam er blevet berørt. Mens Žižeks forhold til buddhismen og islam synes at være entydigt kritisk, har hans engagement med jødedommen og særligt kristendommen været af en mere positiv karakter, og man har i receptionslitteratur ligefrem talt om en 'teologisk vending' i forfatterskabet med de tre 'teologiske' bøger On Belief, The Fragile Absolute og The Puppet and the Dwarf, der alle udkom omkring årtusindskiftet. I sekundærlitteraturen er der blevet fremsat flere forskellige bud på, hvad der kan have motiveret denne teologiske interesse hos Žižek. ${ }^{1}$ Der er givetvis ikke noget entydigt motiv og det er heller ikke afgørende, men det kan imidlertid være oplysende at spørge mere eksplicit til, hvad det er for aspekter ved teologien, som Žižek finder frugtbare i forhold til hans grundlæggende filosofiske og politiske projekt. Her skal nævnes fire sådanne aspekter, hvoraf særligt de to sidste er relevante i nærværende kontekst. For det første tilbyder den kristne tradition en model for et radikalt etisk-politisk engagement, som Žižek henter inspiration til bl.a. hos Paulus' og Pascals troskab imod en mirakuløs begivenhed (Žižek 1999, 127-165). For det andet (gen)finder Žižek hos eksempelvis Paulus og Kierkegaard en (psykoanalytisk)

1 Se fx Boer 2007, 335-390; Kotsko 2008, 71-99; Sharpe \& Boucher 2010, 194-218. 
indsigt i en undertrykkende cirkularitet mellem lov og overskridelse, som udgør en ressource til en dobbelt kritisk besindelse på samtidens reaktioner på modernitetens gennemgribende autoritetsopgør: Reel frihed vindes hverken gennem lovens overskridelse eller lovens genetablering, men i 'afkoblingen' fra lovens og overskridelsens cirkularitet gennem kærlighed til næsten (Žižek 2002c, 192-201). For det tredje rummer den jødisk-kristne tradition fra Jobs afvisning af sine venners forsøg på at retfærdiggøre hans lidelser til Kristi fortvivlelsesråb på korset en grundlæggende ideologikritisk indstilling, der består i at nægte at tilskrive den menneskelige tilværelses lidelse en højere mening (Žižek 2009, 50-57; 2004, 161-162). Denne kritiske indstilling får ifølge Žižek sit mest radikal udtryk med kristendommens tanke om Guds død, fordi denne tanke udgør et opgør med troen på enhver meningsgaranterende instans (Žižek 2003, 171). Med afsæt i den opfattelse, at det at tilskrive tilværelsen mening er indbegrebet af (religiøs) ideologi og at enhver ideologi således implicerer en tro på en instans, der kan garantere en sådan mening, henter Žižek for det fjerde også inspiration fra teologiens refleksioner over tro til sine analyser af samtidens idelogier og til sit forsøg på at forny ideologikritikken (Žižek 1989, 36-47).

Det følgende er som sagt et forsøg på at give en systematisk præsentation af Žižeks begreb om tro. Udgangspunktet for og grundindsigten i Žižeks overvejelser over tro er imidlertid ikke teologisk, men psykoanalytisk. Derfor begynder fremstillingen også hos Freud.

\section{Fetichistisk fornægtelse}

Da Freud i forlængelse af sin revision af den psykoanalytiske personlighedsmodel genovervejer kastrationskompleksets betydning, introducerer han begrebet 'fornægtelse' (Verleugnung) som betegnelse for en specifik forsvarsmekanisme mod kastrationsangst, han ikke tidligere har beskrevet systematisk (Freud 1985a, 163; 1985b, 181). Denne forsvarsmekanisme er et fænomen, som Freud først og fremmest observerer hos fetichisten, dvs. i forbindelse med perversion snarere end tvangsneurose. I sin artikel fra 1927 om fetichisme beskriver han, hvordan det drengebarn, der i sin konfrontation med de kvindelige kønsorganer oplever dette som en verificering af den kastrationstrussel, som det er underlagt, i visse tilfælde samtidig alligevel kan opretholde dets tro på 'kvindens fallos': "Er det ikke rigtigt, at barnets efter sin iagttagelse af kvinden lever videre med en uforandret tro på kvindens fallos? Det har bevaret troen, men også opgivet den [...] der er opnået et kompromis, som kun er muligt i kraft af den ubevidste tankeform (primærprocesserne)" (Freud 1972, 313 [min oversættelse]). Fetichobjektet, der både er symbol på triumfen over og beskyttelse mod kastrationstruslen, fungerer som en (fallos)erstatning, der sætter fetichisten i stand på én og samme tid at anerkende og fornægte kastrationen. Som Freud bemærker, er konsekvensen af denne løsning på den psykiske konflikt mellem kastrationsangst og driftstilfredsstillelse, at fetichisten får en 'tospaltet indstilling' (zweispältige Einstellung, ibid. 316). Det er denne tospaltede indstilling, Freud vender tilbage til i tekstfragmentet "Jeg-splatning i forsvarsprocessen" fra 1938 (se Freud, 
1986). Her beskriver han, hvordan et barn, der tidligere uhindret har kunnet tilfredsstille sine drifter, på traumatisk vis oplever, at den fortsatte driftstilfredsstillelse vil have en vanskelig overkommelig fare til følge (kastration), hvilket stiller barnet i følgende dilemma:

Det må nu bestemme sig: enten anerkende den reelle fare, bøje sig for den og give afkald på driftstilfredsstillelsen, eller fornægte [verleugnen] realiteten, og overtale sig selv til at tro, at der ikke er nogen grund til frygt, hvorved det kan fastholde tilfredsstillelsen.[...] Barnet gør imidlertid ingen af de to ting, eller snarere, det gør begge ting samtidig, hvilket kommer ud på et. Det besvarer konflikten mellem to modsatrettede reaktioner, der begge er gyldige og virksomme. [...] Man må indrømme, at det er en yderst behændig løsning på problemet. Hver af de stridende parter har fået sit; driften kan beholde sin tilfredsstillelse, realiteten får den tilbørlige respekt. Men gratis er som bekendt kun døden. Dette resultat blev opnået på bekostning af en flænge i jeg'et, der aldrig heles igen, men som med tiden vokser sig større. De to modsatte reaktioner på konflikten vedbliver med at bestå som kernen af en jeg-spaltning (Freud 1986, 3-4).

Det væsentlige i denne sammenhæng er nu, at den fetichistiske spaltning af selvet, og den heraf følgende 'tospaltede indstilling', muliggør et særligt selvbedrag, der ikke som det eksempelvis er tilfældet med fortrængning har karakter af et forsøg på at skjule noget for sig selv, men snarere viser sig som en bestemt form for tro, nemlig en tro, der som Freud påpeger, på én og samme tid 'opretholdes' og 'opgives'. Žižek har ved flere lejligheder berørt forbindelsen mellem denne form for tro og selvbedrag, gerne med henvisning til en replik fra en Marx Brothers film, hvor Groucho Marx udbryder: "Hvem tror du på, dine øjne eller mine ord?" Replikken illustrerer ifølge Žižek på perfekt vis, at vores sociale interaktion afhænger af, at vi rent faktisk tror på de symbolske roller, der er på spil i denne interaktion, også selvom de er i modstrid med, hvad vi ved om den konkrete virkelighed $(1999,323)$. Žižek beskriver denne indstilling med reference til Octave Mannonis berømte formel for den fetichistiske fornægtelse 'Je sais bien, mais quand même...' (se Mannoni 1985). Han skriver: "'Jeg ved ganske vist godt, at tingene er på den måde, som jeg ser dem (at denne person er en korrupt svækling), men alligevel behandler jeg ham respektfuldt, da han bærer en dommers emblem, således at når han taler, er det loven selv, der taler gennem ham'” (Žižek 1999, 323). ${ }^{2}$ Vi bedrager altså os selv, ikke ved at skjule (fortrænge) den konkrete virkelighed (der netop anerkendes som den er) for os selv, men i kraft af en tvetydig tro på det symbolske (vi tror på den andens ord til trods for det vi ser med vores egne øjne). Det er værd at bemærke, at Žižek (ibid.) samtidigt understreger, at dét ikke at lade sig bedrage i den socio-symbolske interaktion (dvs. at insistere på at tro på sine egne øjne) imidlertid er et endnu større selvbedrag, fordi man hermed bedrager sig selv til at tro, at bedraget kan undgås. ${ }^{3}$

2 Hvor intet andet fremgår, er oversættelserne af Žižeks tekster mine egne. Det skal bemærkes, at mens fornægtelse for Freud (som fx i den ovenfor citerede passage) kun betegner det ene moment $\mathrm{i}$ den fetichistiske struktur, bruger Žižek begrebet som betegnelse for den samtidige anerkendelse og fornægtelse, altså som betegnelse for begge momenter.

3 Også Kierkegaard har et godt blik for forbindelsen mellem tro og (selv)bedrag, som han bl.a. tematiser på de første sider af Kjerlighedens Gjerninger: "Man kan jo bedrages paa mange Maader; man kan bedrages ved at troe det Usande, men man bedrages dog vel ogsaa ved ikke at troe det Sande; 
Den her skitserede psykoanalytiske indsigt i fornægtelsens mekanisme har spillet en væsentlig rolle i Žižeks vedvarende ambition om at bidrage til en reformulering af den marxistiske traditions ideologikritik (Žižek 2008a, ix-xi). Den har også en afgørende betydning for hans diagnose af samtidens 'postideologiske' ideologi, som han mener netop har fetichismens form (ibid.; Žižek 2002b, 20-23), og som han i forlængelse af Lacan forbinder med en historisk forskydning i subjektivitetens strukturering i relation til loven fra tvangsneurose og hysteri hen imod perversion (Žižek 1999, 248). ${ }^{4}$ Žižek opererer altså med en bestemt kulturhistorisk fortælling om, hvordan perversion, og særligt fetichisme, siden begyndelsen af det 20. århundrede og frem til i dag i stigende grad har afløst hysteri og tvangsneurose som den grundlæggende 'subjektive attitude', og hvordan fornægtelse snarere end fortrængning dermed er blevet den primære psykologiske forsvarsmekanisme.

Men Žižek har også en anden mere grundlæggende strukturel og transhistorisk forklaring på, hvorfor den fetichistiske attitude synes at være allestedsnærværende, nemlig at den er en nødvendig følge af menneskets endelighed, af vores bevidsthed om, at vi skal dø. Žižek fremsætter denne forklaring i forbindelse med en kort, men kompakt refleksion over, hvad vi skal forstå ved (selv)bevidsthed, som han indleder med at foreslå, at Freuds opfattelse af, at der i det ubevidste ingen plads er til forestillingen om vores egen dødelighed, udgør en nøgle til dette spørgsmål (Žižek 2000, 256; Freud 1972b, 341, 350; 1998, 43). Freuds opfattelse bunder i den indsigt, at "Døden kan intet menneske erfare hos sig selv", som Kant formulerer det i sin Antropologi i pragmatisk perspektiv, "men kun iagttage hos andre" (Kant 2000, 60 [min oversættelse]). Freud fremfører blandt andet denne indsigt i sit essay fra 1915 om krig og død, hvor kan skriver følgende:

Vores egen død kan vi ikke forestille os, og så snart vi gør forsøget bemærker vi, at vi i virkeligheden stadig forbliver til stede som tilskuere til den. Derfor kunne den psykoanalytiske skole driste sig til følgende udtalelse: I bund og grund er der ingen, der tror på sin egen død, eller hvad der kommer ud på det samme: I det ubevidste er vi alle overbevidste om vores egen udødelighed (Freud 1972b, 341 [min oversættelse], 350; Freud 1998, 43).

På den baggrund foreslår Žižek, at bevidsthed - i kontrast til Freuds forestilling om dødens fravær i det ubevidste - grundlæggende er en (selv)bevidsthed om sin egen endelighed og dødelighed: "[...] kun 'bevidste' væsner er egentlig endelige og dødelige, kun disse forholder sig til deres endelighed 'som sådan'"' (2000, 256). Og han uddyber:

Bevidsthed [awareness] om ens egen dødelighed er ikke ét i blandt mange aspekter ved

man kan bedrages ved Skinnet, men man bedrages dog vel ogsaa ved det kløgtige Skin, ved den smigrende Indbildskhed, der veed sig ganske sikkret mod at være bedragen" $(2004,9,13)$.

4 Som Žižek flere steder understreger, forstår han ikke psykoanalysens kliniske betegnelser (neurose, psykose og perversion) som objektive sygdomskategorier, men som forskellige "[...] subjektive attituder, 'eksistentielle projekter', som er vokset ud af subjektets konkrete intersubjektive situation og for hvilke subjektet, i kraft af dets frihed, i sidste end selv er ansvarlige" (1994a, 29). For en religionsfilosofisk uddybning af Žižeks diagnose af samtidens 'generaliserede perversion' (Žižek 2002b, 29), se Karlsen 2010. 
selvbevidsthed [self-awareness], men selve dens grundniveau: i en analogi til Kants opfattelse af, at enhver bevidsthed [consciousness] om et objekt involverer selvbevidsthed [self-consciousness], involverer enhver bevidsthed [awareness] en implicit (selv)bevidsthed [self-awareness] om ens egen dødelighed og endelighed (ibid.). ${ }^{5}$

Mennesket er altså et væsen, som på den ene side har bevidstheden om sin egen dødelighed som det mest fundamentale træk ved sin (selv)bevidsthed, men som på den anden ene side ikke har, og aldrig kan opnå, nogen erfaring af sin egen dødelighed, da man (som Kant $(2000,60)$ også bemærker) nødvendigvis må være levende for at gøre sig erfaringer. Ja, man kan, som Freud understreger i citatet ovenfor, ikke engang forestille sig sin egen død, og derfor heller ikke tro på den. ${ }^{6}$ Konsekvensen af denne situation er ifølge Žižek den følgende:

Denne bevidsthed [awareness] [om ens egen dødelighed] bliver dermed fornægtet i kraft af subjektets ubevidste vantro [disbelief] over for hendes eller hans egen dødelighed således, at den grundlæggende model 'Jeg ved ganske vist godt, men...' måske er selve modellen for selv-bevidsthed [self-awareness]: 'Jeg ved ganske vist godt, at jeg er dødelig, men alligevel (så accepter jeg det ikke; ubevidst tror jeg på min egen udødelighed, eftersom jeg ikke kan forestille mig min egen død' (ibid.).

Žižeks radikale påstand synes her at være, at fornægtelse ikke blot skal forstås som en bestemt psykologisk forsvarsmekanisme, der er kendetegnende for fetichisten (som Freud mener) eller mere generelt for enhver form for perversion (som Lacan mener), men at den fetichistiske 'tospaltede indstilling' udgør et konstitutivt træk ved den menneskelige (selv)bevidsthed som sådan.

\section{Tro og viden}

Denne opfattelse har afgørende implikationer blandt andet for Žižeks forståelse af tro, for spørgsmålet om, hvordan vi skal tænke forholdet mellem tro og viden og for spørgsmålet om tro og ateisme. For det første synes det at følge af Žižeks opfattelse af den menneskelige (selv)bevidsthed som værende grundlæggende struktureret efter den fetichistiske model 'jeg ved godt, men jeg tror alligevel', at tro er et uomgængeligt og almenmenneskeligt fænomen, eller med Žižeks ord: "[...] behovet for at tro er uadskilleligt fra den menneskelige subjektivitet [...]" (2002a, 89). Det er således heller ikke så overraskende, når Žižek efterfølgende påpeger, at ingen position er sværere at opretholde end ateismens (ibid.). ${ }^{7}$

5 Se også Žižek 2008, 113. 'Consciousness' og 'awareness' benyttes her tilsyneladende synonymt, hvorfor jeg har valgt at oversætte 'awareness' til 'bevidsthed' snarere end til 'opmærksomhed'. Det er værd at bemærke, at Žižek i det efterfølgende afsnit sætter lighedstegn mellem denne opfattelse af (selv)bevidsthed som det at forholde sig til egen endelighed og følelsen af angst ("consciousness, in effect, equals anxiety"), hvilket synes at vidne om en position, der ikke ligger så langt fra eksistensfilosofiens (jf. Žižek , Butler \& Laclau 2000, 257).

6 For en oplysende teologisk refleksion over dette problem, se Niels Grønkjær 2010, 153-172.

7 Jeg kommer tilbage til spørgsmålet om ateisme nedenfor. 
For det andet betyder den fetichistiske struktur, at der er tale om en særlig form for tro, idet tro her samtidig implicerer et element af viden. ${ }^{8}$ Den konstitutive spaltning af (selv)bevidstheden imellem viden og tro betyder, at vi aldrig bevidst fuldstændig kan overtage vores ubevidste overbevisninger, vi vil altid opretholde en vis distance til dem, for 'vi ved jo ganske udmærket godt' (Žižek 2000, 257). Fetichisten kan kun tro på en distanceret måde. Det betyder imidlertid samtidig, at troen ikke undergraves af, men snarere bestyrkes gennem viden, fordi viden giver mulighed for at distancere sig fra, og dermed netop opretholde, en distanceret tro. I modsætning til den gængse opfattelse udelukker tro og viden således ikke gensidigt hinanden, tværtimod tror fetichisten ikke alene på trods af sin viden, men altså i kraft af denne viden (Mannoni 1985, 12-13). ${ }^{9}$ Derfor lader fetichismen sig heller ikke 'kurere' gennem oplysning. Man kan opsummere de to første punkter (i omvendt rækkefølge) med Žižeks ord: "På den ene side er der ingen, som fuldt ud kan antage en tro i første person ental. [...] Imidlertid er der på den anden side ingen, som rent faktisk undslipper troen [...] vi tror alle sammen inderst inde" $(2002 \mathrm{a}, 88)$.

For det tredje resulterer denne distance (ingen kan fuldt ud påtage sig at tro i første person ental) til vores egen tro i en forskydning af vores tro til en andens tro, således at vores tro altid er en 'refleksiv tro', en tro på den andens tro: "Forestillingen om tro involverer i sig selv en forestilling om 'subjektet, der formodes at tro', om et andet subjekt på hvis tro jeg tror" (Žižek 2000, 134; 1993, 202; 1994a, 38; 2008b, 138). Žižek understregerer, at denne forskydning af troen til en tro på den andens tro er 'oprindelig og konstitutiv', hvilket netop skal forstås på baggrund af hans opfattelse af bevidsthedens grundlæggende fetichistiske karakter, og at forestillingen om et 'subjekt, der formodes at tro' derfor udgør en 'strukturel nødvendighed' (2008b, 135, 139). Den anden, der formodes at tro, og som tror for os, behøves ikke være en anden person, som fx vores børn, som (vi tror) tror på julemanden. Det kan ifølge Žižek også være en ting, fx et tibetansk bedehjul (2008b, 134-144; 1989, 34). ${ }^{10}$ Troen får således i modsætning til en traditionel protestantisk-pietistisk opfattelse af tro samtidig karakter af noget ydre og 'objektivt' snarere end noget indre og 'subjektivt', noget som "[...] er legemliggjort i folks praktiske procedurer" (Žižek 1989, 34, 36). At troen er 'legemliggjort' betyder, at andre personer, ting eller 'procedurer' kan tro for os, og at vi kan tro igennem dem, men også, at det er i kraft af de materielle anordninger, vi indgår, at vi tror. En pointe, som Žižek anskueliggør med en reference til Pascal, som eftersigende skulle have svaret en ven, der beklagede sig til ham over sin manglende tro: "[...] knæl ned, opfør dig som om du tror og så vil troen komme af sig selv" $(2008,5 ; 1989,39)$. Eller pointen er måske rettere som Žižek præciserer et andet sted: "Knæl ned og du vil således få en anden til at tro!" I kraft af ri-

8 Som Robert Pfaller (2014, 6-9) har vist kan det være en mere frugtbar tilgang for en analyse af tro at spørge til troens form end dens indhold, at spørge til, hvordan der tros snarere end, hvad det tros på.

9 Se Pfaller $(2014,39-44)$ for en mere omfattende udfoldelse af denne pointe omkring forholdet mellem tro og viden.

10 Som Žižek (2008b, 139) gør opmærksom på behøver den anden, der formodes at tro (direkte) end ikke at eksistere for, at troen kan være virksom, det nok at tro på denne andens eksistens. 
tualet kommer vi til at tro - distanceret - på den andens tro $(2006,353)$. Rituel aktivitet kan altså generere (forskudt) tro, men det kan som Žižek påpeger også være en måde at slippe af med sin (nærgående) tro på: "At tro - at tro 'direkte' uden ritualets yderliggørende mediering - er en voldsom, tyngende, traumatisk byrde, som man ved at praktisere et ritual har en chance for at overføre på en Anden" (2006, 353-354). Konsekvensen af, at troen på denne måde er forskudt, yderliggjort og objektiv, er på den ene side, at vi ikke selv behøver at tro for at tro, fordi den anden kan tro for os, og på anden side, at vi selvom vi ikke selv tror (at vi tror), tror vi alligevel gennem og på den anden (i de ritualer og praksisser vi indgår i).

Som antydet synes Žižek at operere med et skel mellem to aspekter af eller former for tro: på den ene side en tro som ingen kan antage $\mathrm{i}$ første person ental og som derfor altid er en tro, der forskudt til (en tro på) den anden(s) (tro), og på den på anden side en tro, som ingen slipper for at antage, og som derfor netop er en tro i første person ental (2002a, 88). Denne skelnen optræder også - i næsten ordret gengivelse - i en passage fra Om troen. Her ekspliciterer og videreudfolder Žižek skellet med henvisning til den distinktion mellem 'croyance' og 'foi', som Mannoni udvikler i sin klassiske tekst om fetichisme, og som Žižek bestemmer som forskellen mellem at have 'tillid til' (faith/foi) noget, som viser sig i et forpligtende engagement, og at 'tro på' (belief/croyance) noget uden dermed nødvendigvis at sætte sin lid til det (Žižek 2002b, 133; Mannoni 1985, 13-14). Žižek forbinder samtidig dette skel mellem 'tillid til' og 'tro på' med Lacans tre registre, idet han beskriver dem som henholdsvis en 'symbolsk' tro (faith) og 'imaginær' tro (belief) (se Lacan 1992). ${ }^{11}$ Han skriver: "[...] troen i forbindelse med den imaginære 'tro på' [belief in] [er] altid forskudt tro [belief] (det er aldrig mig, som i første person ental er villig til at antage en tro, behovet vil altid være der for fiktionen om et 'subjekt, der formodes at tro'), hvor det i tilfældet med den symbolske tro [faith] forholder sig sådan, at forpligtelsen performativt antages i første person ental" (Žižek 2002b, 133 [oversættelsen er modificeret]; 2001, 110). Hvordan forholder disse to former for tro sig så til hinanden?

I passagen fra Om troen påpeger Žižek, at de hver især kan forekomme isoleret eller afskilt fra hinanden. Således kan man godt 'tro på' (believe) noget (for eksempel spøgelser) uden at have 'tillid til' (faith) det og omvendt have 'tillid til' noget uden at 'tro på' det, hvilket Žižek illustrerer med en henvisning til Lacans begreb om den symbolske orden, som man sagtens kan have 'tillid til', selvom man ikke 'tror på' den, idet man godt ved, at den ikke er andet end en virtuel orden uden nogen substantiel eksistens, en fælles fiktion, der alene opretholdes ved at man agerer, som om den eksisterer (Žižek 2002b, 133; 2001, 109). Žižek bemærker efterfølgende, at netop på grund af denne samtidighed af viden ('jeg ved godt, at den symbolske orden blot er en fælles fiktion') og symbolsk tro (faith) ('alligevel har jeg tillid til den'), får den imaginære tro (belief) altid karakter en forskudt tro ('det er ikke mig, der tror på den symbolske orden') på den anden, der formodes at tro (på den symbolske orden). Men hvordan er den symbolske tro og den imaginære tro mere præcist forbundet?

11 Žižek $(1985,17)$ følger her tilsyneladende Mannoni. 
En måde at tage fat på dette spørgsmål på er ved at knytte an til Žižeks tilbagevendende diskussion af Louis Althussers ideologibegreb (1989; 1994b; 2000)

Som udgangspunktet er det værd at bemærke, at Žižek i forbindelse med denne diskussion eksplicit fremsætter et skel mellem to former for tro ('two beliefs'), og at han igen bruger termerne 'tro på' (belief) og 'tillid til' (faith) til at markere forskellen mellem disse to former for tro $(2000,119)$. Den sidstnævnte form for tro beskrives som en "[...] 'tom' tro, der er på spil, når vi indgår i en symbolsk proces 'i tillid' [on faith]", mens den førstnævnte imaginære tro karakteriseres som "[...] den fulde tro på [belief in] en sag." Selvom Žižek ikke her på samme måde som i Om troen eksplicit benytter betegnelserne 'symbolsk' og 'imaginær', så antyder beskrivelsen af den 'tomme' tro som en tillid, der er på spil i en symbolsk proces, at der er tale om en skelnen, som svarer til den, han opererer med i Om troen. Hvad Žižek nærmere bestemt mener med betegnelserne 'tom' (empty) og fuld' (full) angiver han ikke direkte, men han giver et fingerpeg om det, når han i den efterfølgende passage skriver om den symbolske tro, at den er "[...] det Derrida har i tankerne, når han taler om det 'oprindelige Ja!', der konstituerer det minimale engagement; den er det Lacan tænker på, når han udlægger den Freudianske Bejahung som den oprindelige accept af den symbolske orden" (ibid.). ${ }^{12}$ Žižeks pointe synes altså at være, at den symbolske tro (faith) er 'tom' fordi den, i modsætning til den imaginære tro (belief) på en bestemt, konkret sag, ikke har noget indhold andet end sig selv - den er en tro på selve det at tro, altså netop en grundlæggende (minimal) bekræftelse eller accept. ${ }^{13}$ Endvidere antyder begreberne 'det oprindelige ja' og 'den oprindelige accept', at Žižek tænker forholdet mellem den 'tomme' (symbolske) tro (faith) og den 'fulde' (imaginære) tro (belief), som et forhold, hvor førstnævnte går forud for sidstnævnte.

Denne opfattelse bekræftes i Žižeks diskussion af Althussers henvisning til Pascal i Ideologi og ideologiske statsapparater (1989, 36, 43; Althusser 1983, 47-48). I en passage vedrørende Pascals forståelse af, hvorfor vanen ikke kan reduceres til 'åndforladt behavioristisk visdom' om, at indholdet af vores tro altid er betinget af vores adfærd, fremhæver Žižek som korrektion til Althusser, at det kan den ikke, fordi Pascals opfattelse indbefatter tanken om en ubevidst 'tro før tro' (belief before belief) (ibid. 40; Pascal 1995, 247). Forud for vores bevidste tro på (en given sag), der frembringes og understøttes gennem de sociale praksisser og ritualer, som vi indgår i, har vi allerede en ubevidst tro (på selve det at tro), som vi ikke kan komme bagom og som udgør forudsætningen for, at vi lader os indrulle i bestemte ritualer og praksisser til at begynde med (Žižek 2000, 119). Det betyder dog ikke, at disse praksisser og ritualer er ligegyldige for troen. Tværtimod: "Religiøs tro er ikke blot, eller endsige først og fremmest, en indre overbevisning, men kirken som institution og dens

12 Se herom hos Derrida 1987, 57-143 og Lacan 1966, 381-399.

13 Til støtte for en sådan læsning, se Žižek 1993, 202. De ovenfor citerede passager er fra et afsnit i bogen Contingency, Hegemony, Universality, hvor Žižek diskuterer Mladen Dolars artikel "Beyond Interpellation" om ideologi hos Althusser og Lacan. Žižek forsvarer her Dolars skel mellem en tro, som opstår i kraft af deltagelsen i et ritual og så en 'minimal' ubevidst 'tro før tro' (Žižek 1989, 40, 43). Denne ubevidste tro beskriver Dolar 1993, 90 som en 'ren formel tro uden noget indhold' og som 'en tro på, at der er noget at tro på.' 
ritualer (bøn, dåb, konfirmation, skriftemål...), der langt fra er en simpel sekundær eksternalisering af indre overbevisning, repræsenterer selve den mekanisme, som genererer den" (Žižeks 1994b, 12). Ritualer og sociale praksisser frembringer ikke alene en bevidst tro på noget bestemt hos dem, der indgår i dem, men skaber også retroaktivt denne tros begrundelse. Žižek formulerer det med henvisning til Pascal på følgende måde: "[D]en implicitte logik i hans argument er: Knæl ned og du vil tro, at $d u$ er knælet ned på grund af din tro - med andre ord, [du vil tro] at dét, at du følger ritualet er et udtryk for/en effekt af din indre tro. Kort sagt, det ydre ritual generer performativt dets eget ideologiske grundlag" (1994b, 12; 1989, 40; 2006, 353). Forudsætningen for dette er imidlertid som sagt en ubevidst 'tro før troen'.

Der er, som Žižek påpeger, en form for retroaktiv skabelse og omvendt kausalitet på spil i troen: man knæler ned for at komme til at tro med det resultat, at man kommer til at tro, at man knælede ned fordi man (allerede) tror (1994b, 12). Denne omvendte kausalitet involverer en slags tidsloop, hvor nutiden bestemmer fortiden snarere end omvendt, som svarer til det, Freud beskriver eksempelvis i forbindelse med hans behandling af den såkaldte 'ulvemand', der først senere i livet, på baggrund af en relativ uskyldig episode, nu oplever en episode, hvor han som lille barn har overværet forældrenes coitus a tergo, som traumatisk (Žižek 1994a, 32, 39 Freud 1984, 115-116). ${ }^{14}$

Opsummerende kan man sige, at Žižek tilsyneladende skelner imellem og opererer med to forskellige former for tro: på den ene side en 'fuld' (imaginær) tro, der er struktureret som den fetichistiske fornægtelse, hvor troen som en tro på den andens tro på én og samme tid er opgivet og bevaret, og på den anden side en 'tom' (symbolsk) forudgående, ubevidst tro på selve det at tro.

\section{Ateismens $(\mathrm{u})$ mulighed?}

At vores tro har form af en forskudt tro på den anden, der formodes at tro (fundamentalisten, præsten, barnet, de uuddannede, osv.) betyder ifølge Žižek, at vi i dag - til trods for, at vi forstår os selv som sekulære, illusionsløse, oplyste fritænkere tror meget mere end vi tror, vi gør $(2003,6$; 2006, 352). At forudsætningen for denne form for tro er en grundlæggende, ubevidst 'tro før troen' på selve det at tro, er ifølge Žižek det, der gør at 'intet er sværere end at opretholde en ateistisk position' (2002a, 89). Hvad han nærmere bestemt mener hermed søger han at uddybe med udgangspunkt i Lacans bemærkning om, at "[...] ateismens virkelige sætning er ikke Gud er død [...] ateismens virkelige sætning er Gud er ubevidst" $(2004,55)$. Dette, at Gud er ubevidst, betyder som Žižek påpeger i The Monstrosity of Christ, at:

For at være ateist er det ikke længere tilstrækkeligt at erklære, at man 'ikke tror (på

14 Se også Freuds eksempel med Emma i Udkast til en videnskabelig psykologi (1980, 109-113). Det er dette retroaktive og retarderende aspekt ved erfaringsdannelsen, hvor nutiden i en slags omvending af tidens retning virker tilbage på fortiden således, at erfaringen (om)skabes af fortiden og først indtræffer forsinket, som Freud forsøger at indkredse med dannelsen af begrebet nachträglichkeit (se Laplanche \& Pontalis 2006, 111-114). 
Gud)', da det egentlige sæde for min tro ikke er mine bevidste handlinger, men det ubevidste. Dette er naturligvis ikke det samme som det psykologiske nonsens om at 'selv om jeg forsøger at benægte Gud, fortsætter jeg dybt i mig selv med at tro' - det ubevidste er ikke 'dybt i mig', det er derude, legemliggjort i mine praksisser, ritualer og interaktioner. Selv hvis jeg ikke tror subjektivt, tror jeg 'objektivt', i og gennem mine handlinger og symbolske ritualer. Det betyder også, at religion, religiøs tro, er langt dybere forankret i 'den menneskelige natur' end det kan synes: dens ultimative understøtning er illusionen om den 'store Anden', som på sin vis er det samme som selve den symbolske orden. Den sande formel for ateisme er ikke 'jeg tror ikke', men 'jeg behøver ikke længere forlade mig på en stor Anden, der tror for mig' - den sande formel for ateisme er 'der er ingen store Anden' $(2009,297)$.

Der er flere ting i denne passage, som er værd at opholde sig lidt ved. For det første, kalder Žižeks udsagn om, at troen (på Gud) snarere er til stede i det ubevidste end i det, vi bevidst foretager os, på en uddybning af, hvad der menes med 'det ubevidste'. Det er væsentligt i denne sammenhæng, at det ubevidste, som Žižek understreger, ikke forstås som et 'indre' individuelt, dybt i psyken begravet, skjult domæne af blinde irrationelle instinkter, men snarere som et mellemværende, en overindividuel strukturering af den symbolske og libidinøse interaktion, som udfolder sig i sociale praksisser, og således i en vis forstand noget 'ydre'. Eller rettere sagt med en af Lacans neologismer: Det ubevidste er 'ekstimt' (extimité), en eksteriør intimitet, noget fremmed og ukendt i hjertet af det kendte (se Lacan 1986, 167). Žižek beskriver således det ubevidste som noget, vi ikke ved, at vi ved (unknown knowns) (2005, 52); en form for viden, der ikke ved af sig selv, som han forbinder med selvrefleksivitet og selvbevidsthed:

Det ubevidste er ikke en form for før-refleksiv, før-tetisk, primitive substrat, der senere bearbejdes ved bevidst refleksivitet; tværtimod, hvad der er mest radikalt 'ubevidst' hos et subjekt er selve hans selvbevidsthed, den måde, hvorpå han refleksivt forholder sig til sine bevidste holdninger (Žižek 2012, 554; 2010, 227).15

Det ubevidste synes med andre ord at udspille sig i forholdet mellem vores forhold til os selv og vores forhold til den anden, i vores måde at forholde os til os selv på i vores forhold til den anden og vice versa.

For det andet: Hvad betyder det, at 'den store Anden' som en illusion, der understøtter troen, ikke eksisterer? Lacans begreb om den store Anden er et komplekst og mange-facetteret begreb, men helt overordnet kan man sige, at det er betegnelsen for en upersonlig, medierende og (ikke mindst) normerende instans, der altid implicit adresseres og gør sig gældende som en uudtalt 'tredje part' i enhver symbolsk interaktion og kommunikation mellem to (eller flere) personer. ${ }^{16}$ Žižek skitserer det på denne måde:

15 Det skal nævnes, at selvrefleksion for Žižek (1992, 89)aldrig lykkes fuldstændigt, dvs. der er altid en blind plet, noget ugenkendeligt, i selvrefleksionen. Det er også dette moment af fejl ved selvrefleksiviteten, som Žižek forbinder med det ubevidste (ibid.).

16 Som Žižek understreger, opererer den store Anden på et symbolsk niveau - ofte virker det endda, som om han helt sætter lighedstegn mellem den store Anden og den symbolske orden (som fx i citatet oven for) $(2005,9)$. 
Hvordan kan det være at, når enkeltpersoner udveksler symboler, interagerer de ikke blot med hinanden, men de henviser også altid til den virtuelle store Anden? Når jeg taler om andre folks meninger er det aldrig kun et spørgsmål om, hvad jeg, du, eller andre personer tænker, men også et spørgsmål om, hvad det upersonlige 'man' tænker. Når jeg overtræder en bestemt regel for anstændig opførsel, gør jeg aldrig blot noget, de fleste andre ikke gør - jeg gør, hvad 'man' ikke gør $(2005,11)$.

Der er således altid en fordobling af den anden - den konkrete anden og den store Anden ('man') - på spil i enhver symbolsk interaktion. "Menneskelig kommunikation er" som Žižek $(2005,12)$ formulerer det "karakteriseret ved en irreducibel refleksivitet." At den store Anden, som altså i sidste ende udspringer af en uomgængelig refleksivitet, ifølge Žižek er en 'illusion', referer til dens virtuelle karakter: "Den eksisterer kun for så vidt, at vi agerer som om den eksisterer" $(2005,10)$. Men netop fordi vi agerer som om den er virkelig, virker (illusionen om) den store Anden også ind på vores virkelighed. Troens sidste fundament er denne ubevidste illusion, som Žižek identificerer med Gud bl.a. fordi den store Anden fungerer "[...] som 'subjektet, der formodes at vide', som Mesteren, der ser alt og hemmeligt trækker i trådene" (2012, 95). I den citerede passage fra The Monstrosity of Christ forbinder Žižek imidlertid også den store Anden med 'subjektet, der formodes at tro'. Det vil sige den store Anden er ikke alene den alvidende og almægtige instans, som vi forestiller os ved og kan det, vi ikke selv ved og kan, men også den ubetvivlelige instans, der garanterer, at der er nogen, der tror, og at der er noget at tro på selvom vi ikke selv tror (at vi tror) på, at der er det. Men hvad vil det så sige 'ikke at forlade sig på den store Anden'?

Det spørgsmål fører til et tredje forhold, der er værd at bemærke ved den omtalte passage, nemlig at Žižek til sidst i citatet skriver, at "Den sande formel for ateisme er ikke 'jeg tror ikke' [...]." Han synes hermed at antyde, at ateisme og tro ikke nødvendigvis skal ses som hinandens modsætninger. Tidligere i The Monstrosity of Christ foreslår Žižek da også, at en sand ateisme involverer en 'tilbagevenden til tro (faith)' - ja, han går endda så langt som til at hævde, at 'kun ateister kan tro på en sand måde' $(2009,101)$. Også i Less than Nothing fra 2012 kommer Žižek ind på denne sande, eller som han formulerer det her, 'autentisk tro', som ateismen indebærer. I en illustrativ passage forklarer han, at:

Autentisk tro er at modsætte sig afhængigheden af (eller henvisningen til) et (andet) subjekt, der formodes at tro: $i$ en autentisk handling af tro påtager jeg mig selv fuldt ud min tro og har således ikke behov for en skikkelse af den Anden til at garantere denne tro; for at parafrasere Lacan, en autentisk tro ne s'authorise que de lui-même. Autentiske tro i denne præcise forstand har ikke blot ikke brug for at forudsætte nogen stor Anden (det er ikke en tro på en stor Anden), men forudsætter derimod opgivelsen af den store Anden, den fulde accept af dens ikke-eksistens $(2012,118)$.

Žižek giver her en dobbeltbestemmelse af autentisk tro som både et negativt og et positivt forhold. På den ene side som det 'at modsætte sig afhængigheden af et subjekt, der formodes at tro', 'ikke at have behov for den Anden til at garantere troen', eller som det lød i Monstrosity of Christ'ikke at forlade sig på den store Anden, der 
tror for mig', og på den anden side som det 'at jeg selv i en autentisk handling af tro fuldt ud påtager mig min tro'. Referencen til det sidstnævnte aspekt ved ateismens autentiske tro dukker også op i Žižeks kritik af samtidens religiøse fundamentalisme, som han kontraintuitivt sidestiller med dens tilsyneladende modpol:

Liberal-skeptiske kynikere og fundamentalister deler et grundlæggende træk: tabet af evnen til at tro i ordets rette betydning. Hvad der er utænkeligt for dem, er den grundløse beslutning, som installerer en autentiske tro, en beslutning, som ikke kan baseres på en række argumenter, på positiv viden $(2005,117) \cdot{ }^{17}$

Fundamentalisten og skeptikeren anser begge religiøse udsagn for at være 'kvasiempiriske vidensudsagn', som de så henholdsvis accepterer og affejer (ibid.). Kort sagt, begge parter behandler tro som om det var et spørgsmål om viden. Den autentiske tro, som Žižek modstiller denne dobbelte reduktionen af troen til viden, er ikke kun risikabal i sin grundløshed, for som Žižek påpeger i en anden sammenhæng, så udgør det 'ikke at forlade sig på den Anden', det 'at acceptere den symbolske ordens ikke-eksistens', en form for 'kvasi-psykotisk gestus' (2008a, 127). Den afgørende forskel er dog, at selvom den psykotiske (fx den paranoide) mistroisk afviser den symbolske orden (den store Anden) som et bedrag, så fastholder han samtidig en tro på en skjult manipulator, der står bag dette bedrag (Žižek 1991, 81).

I disse overvejelser over en 'sand ateisme' skelner Žižek, som antydet, igen mellem to typer af tro. På den ene side en ubevidst, fetichistisk tro på den anden, der formodes at tro, som er funderet i den stores Andens autoritet, og på den anden side en ubegrundet, grundløs tro, der baserer sig på en accept af den store Andens ikke accept. Spørgsmålet er, hvordan denne skelnen forholder sig til den ovenfor skitserede skellen, som Žižek foretager mellem en imaginær (fuld) forskudt tro (belief) på den anden, der tror, og en symbolsk (tom) tro i form af en 'oprindelig' tillid (faith)? Er det en anden udgave af den sammen skelnen, eller introducerer Žižek her et tredje register, en tredje form for tro, som man måske passende kunne kalde reel tro eller tro på det reelle? Noget, der kunne tale for, at Žižek med forestillingen om en ateistisk tro introducerer en tredje (reel form for tro, er at han i den skellen, han fortager i diskussionen af autentisk tro og troen på den store Anden, ikke, som det var tilfældet i hans skellen mellem imaginær og symbolsk tro, benytter sig af begreberne belief og faith til at indikere forskellen. Et andet, mere væsentligt, argument er, at Žižeks karakteristik af den autentiske tro i langt højere grad stemmer overens med definitionen på det reelle end på det symbolske. På de sidste sider af The Sublime Object of Ideology beskriver han da også netop det 'at antage den store Andens ikkeeksistens' som værende det samme som 'at acceptere det reelle' $(1989,230) .{ }^{18}$

17 Desværre præciserer Žižek hverken her eller andre steder, hvor han (fx 2006, 348) beskriver autentisk tro som (aktiv) beslutning og handling, hvordan dette nærmere skal forstås. Det kunne have været interessant at sammenligne med den trosforståelse, som man finder eksempelvis i den lutherske tradition, hvor tro tænkes som en passivitetserfaring (en gave fra Gud), der nok må fastholdes i en aktiv tillid, som kommer til udtryk i (besluttede) handlinger (Prenter 1958, 40-41).

18 Som en afsluttende parentes skal det påpeges, at Žižeks tese om sand ateisme er en dobbelt tese: Ikke blot er ateister de eneste sande troende; men kristendommen er den eneste sande ateisme (2012). Kristendommen er med sin forestilling om Guds død ifølge Žižek $(2003,15)$ den eneste kon- 


\section{Afslutning: religionsfilosofisk perspektivering}

Den religionsfilosofiske relevans af Žižeks analyser af tro har flere forskellige aspekter. De er oplagt relevante for religionsfilosofiens forpligtelse på en løbende afklaring af trosbegrebet og for den tilbagevendende og centrale diskussion om forholdet mellem tro og viden. Men Žižeks analyser er også relevante i en mere overordnet forstand. De kan nemlig bidrage til en mere nuanceret forståelse af religionsfilosofi, idet de - på en uudtalt måde - problematiserer en udbredt opfattelse af, hvad religionsfilosofi er. ${ }^{19}$ Det er en opfattelse, der tager afsæt i en forståelse af religion som en særlig sfære eller et bestemt område af den menneskelige tilværelse. Ud fra det afsæt bliver religionsfilosofi bestemt som en form for 'anvendt filosofi', hvor filosofiens fremgangsmåder og grundbegreber er overført til og appliceret på religionens område. Žižeks analyser af tro problematiserer en sådan opfattelse, ikke alene i den forstand han viser, at tro gør sig gældende i mange forskellige sammenhænge, der ikke umiddelbart har noget med religion at gøre, men især fordi han med denne indsigt i, at et religiøst fænomen som tro ikke kan afgrænse til en særlig sfære eller et bestemt område samtidig peger på religion som noget fundamentalt menneskeligt, noget, der har at gøre med selve menneskets måde at være til på. For en religionsfilosofi, der tager afsæt i opfattelsen af religion som et afgrænset område, er det let at overse dette. Men hvad betyder det så, at religion har noget med menneskets måde at være til på, og hvordan kommer det mere præcist til udtryk i forhold til Žižeks forhold til religion?

En måde at tage fat på den første del af spørgsmålet på, er, at begynde med en anden bestemmelse af hvad religion er, nemlig at religion er en måde at forholde sig til det ved den menneskelige tilværelse, der overskrider den. Eller anderledes formuleret: religion udgør en måde hvorpå mennesket forholder sig til grænserne for det menneskelige. Religionen giver svar på, men rejser dermed også implicit, spørgsmålet om grænserne for det at være menneske. Det er igennem de svar den giver på spørgsmålet om, hvad mennesket ikke forstår og ikke formår, at religionen forstår det menneskelige. I religionen forholder mennesket sig således til det ikkemenneskelige eller umenneskelige ved den menneskelige tilværelse. Mennesket forholder sig i religionen til det ved dets tilværelse, som underdrager sig dets forståelse og magt og som sætter sig igennem på trods af heraf, det, som samtidig også

sekvente ateisme, fordi denne forestilling indebærer tanken om, at Gud dør for sig selv, og ikke blot som i alle andre former for ateisme, at Gud dør for os. Med Kristi råb på korset ('min Gud, min Gud, hvorfor har du forladt mig!') repræsenterer kristendommen for Žižek en ateisme, som har indset, at det ikke alene er os (mennesket), der ikke tror på Gud, men at Gud heller ikke tror på sig selv - og han kan derfor ikke fungere som 'den store Anden, som tror for mig'. For en klar og præcis videreudfoldelse af dette, se Lars Sandbeck 2016.

19 Det følgende trækker på Arne Grøns mere generelle refleksioner over religionsfilosofi herunder forholdet mellem religion og filosofi, og forholdet mellem religion og det menneskelige (2002; 2008). 
er det, hvori det overskrider sig selv og som gør det i stand til det umenneskelige. ${ }^{20}$ Hermed forholder det sig samtidig til sig selv som menneske, idet det umenneskelige som det menneskeliges grænses har en konstitutiv betydning for det menneskelige (se Žižek 2006, 123). Der er således et menneskeligt anliggende i religion, og religion er menneskelig i den forstand, at mennesket i religion forholder sig til sig selv som (u)menneskelig.

Opfattelsen af religion som noget menneskeligt, endog alt for menneskeligt, kendes også fra den moderne religionskritiks koryfæer, Feuerbach, Marx, Nietzsche og Freud, der alle opererer med den såkaldte projektionstese: menneskets guder er ikke andet end projektioner af mennesket selv, ikke andet end menneskets udlægning af sig selv i en anden, guddommelig skikkelse. ${ }^{21}$ Gennem en sådan udlægning kommer mennesket ved at stå over for sig til bevidsthed om sig selv. Men i og med at mennesket udlægger sig selv i en anden (guddommelige) skikkelse, gør det sig i sin selvbevidsthed samtidig fremmed for sig selv. Det betyder imidlertid også, at selvom religion ikke er andet end menneskets udlægning af sig selv, så er mennesket i religionen noget andet end sig selv, noget udover sig selv, noget umenneskeligt. Men det fremmede eller andet som mennesket er i religionen lægges i religionen samtidig over i noget andet end mennesket selv (det guddommelige), således at mennesket aflægger det fremmede og umenneskelige, det er. Det fremmede og umenneskelige ved sig selv som mennesket kan blive opmærksom på i religionen kan altså også skaffes af vejen i religionen, så det ikke længere er et problem, der angår mennesket, men kun religionen, som så kan kritiseres som fremmedgørende.

De to her skitserede indsigter, at selvom om religionen er menneskelig alt for menneskelig kan den ikke reduceres til noget rent menneskeligt, og den fremmedgørelse fra sig selv, som mennesket udsættes for, men også kan blive sig bevidst om, i religionen, har sin grund i noget fremmed, noget umenneskeligt, hos mennesket selv, findes også hos Žižek. De findes implicit i hans analyser af troen og mere eksplicit, som vi skal se, i hans problematisering af den feuerbachske og marxske religionskritik og i hans forbehold overfor en humanistisk ateisme.

I den kritik af den feuerbachske og marxske religionskritik, som Žižek ved flere lejligheder har fremført, er hans hovedanke, at menneskets fremmedgørelse ikke, som det hævdes i denne tradition, er en 'forvrængning' af mennesket sande væsen, og at alt hvad vi derfor behøver at gøre for at sætte mennesket fri er at gentilegne os dette sande væsen gennem en afsløring af eksempelvis religions fremmedgørende virkninger (1989, 225-227; 1993, 29-39; 2009, 75). For Žižek er menneskets fremmedgjorthed tværtimod selve grundlaget for den menneskelige subjektivitet og dermed dets frihed; menneskets fremmedgørelse er ikke noget, der skal overvindes, men er derimod det, der definerer den menneskelige tilstand som sådan (Žižek 1989, 5). Af samme grund kan religionen heller ikke blot reduceres til en ren menneskelig pro-

20 'Lidenskab' kunne være en (Kierkegaardsk) betegnelse for dette (u)menneskelig ved den menneskelige tilværelse. Hos Žižek $(2006,123)$ indkredses det (u)menneskelige først og fremmest med i afsæt i psykoanalysens driftsbegreb.

21 For en detaljeret udfoldelse af den tankegang, der blot antydes her, se Arne Grøns artikel "Intet andet end - Andet end: Religionskritikkens nødvendighed, problem og mulighed" (Grøn 2009). 
jektion. Eller som han forklarer i et interview med den sigende titel 'Humanisme er ikke nok':

Mine venner spørger mig altid: 'Men hvorfor kan ikke du bare kalde det humanisme, hvorfor bliver du ved med at kalde det teologi? Er din tese ikke den unge Marxs feuerbachske tese, at Helligånden egentlig bare er menneskehedens ånd, der er ingen Gud.' For præcise grunde, som jeg kan uddybe - Nej. Humanismen er ikke nok. På samme måde som Freud taler om metapsykologi. Der skal være en dimension over det. Teologi er et andet navn for metapsykologi, for noget, der er i mennesket og er mere end mennesket, den umenneskelige kerne i mennesket etc. [...] Gud er blot et navn for dette tomrum, denne åbenhed, dette umenneskelige, mere end mennesker (Žižek 2007, 19).

På trods af det lille, men tydelige 'blot' til sidst i citatet kan man sige, at for Žižek er det ikke nok, og ikke dialektisk nok, blot at hævde, at 'teologi er antropologi', man må samtidig have med, at 'antropologi er teologi. ${ }^{22}$ Som menneske er mennesket også noget andet og mere end menneske, og kun i forholdet til dette andet (umenneskelige) bliver mennesket menneske. At fastholde det, vil sige at åbenholde mennesket som problem eller spørgsmål, eller i Žižeks termer at acceptere og tro på det reelle.

\section{LITTERATUR}

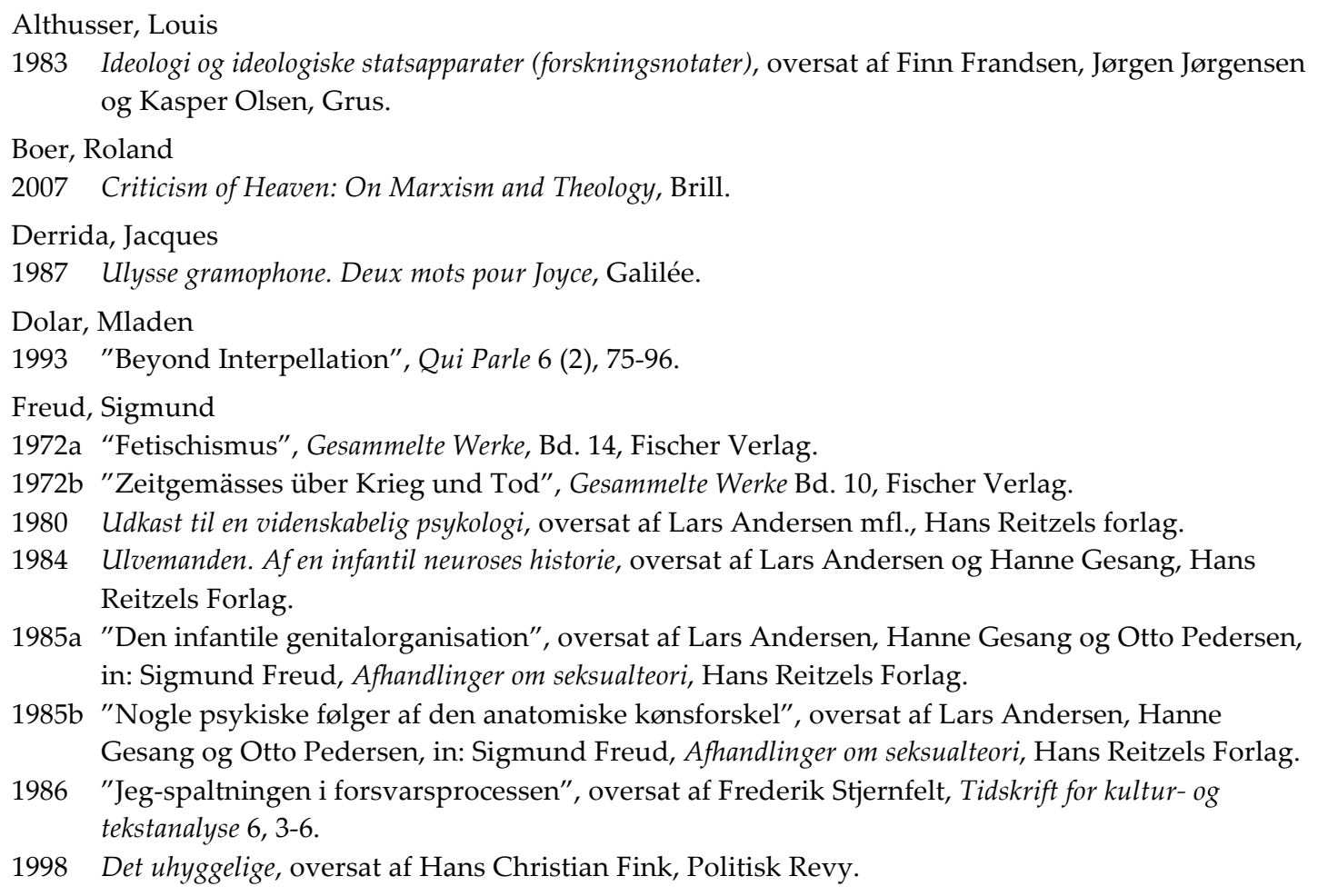

22 For en mere eksplicit teologisk udlægning af denne tanke, se Grønkjær 2010, 45-46. 
Grøn, Arne

2002 "Religion as Philosophical Challenge", Svensk Teologisk Kvartalskrift 78 (3), 134-139.

2008 "Religion and (in)humanity", Florida Philosophical Review 8 (1), 1-12.

2009 "Intet andet end - Andet end: Religionskritikkens nødvendighed, problem og mulighed" in: Mads Peter Karlsen \& Lars Sandbeck, eds., Religionskritik efter Guds død, Forlaget Anis.

Grønkjær, Niels

2010 Den nye Gud. Efter fundamentalisme og ateisme, Forlaget Anis.

Kant, Immanuel

2000 Anthropologie in pragmatischer hinsicht, Felix Meiner Verlag.

Karlsen, Mads Peter

2010 "From a Perverse to a Suffering God - On Slavoj Žižek's Materialist Reading of G.K. Chesterton", International Journal for Žižek Studies 4 (4), 1-24.

Kierkegaard, Søren

2004 Kjerlighedens Gjerninger. Søren Kierkegaards Skrifter, Bd. 9, Gads forlag.

Kotsko, Adam

2008 Žižek and Theology, T \& T Clark.

Lacan, Jacques

1966 Écrits, Édition Seuil.

1986 Le séninaire livre VII. L'ethique de la psychoanalyse, Seuil.

1992 "Det symbolske, det imaginære og det reelle", oversat af Per Aage Brandt, Almen Semiotik 5, 824.

2004 Psykoanalysens fire grundbegreber - seminar XI, Politisk Revy.

Laplanche, Jean \& Pontalis, Jean-Bertrand

2006 The Language of Psychoanalysis, translated by Donald Nicholson-Smith, Karnac Books.

Mannoni, Octave

1985 "Je sais bien, mais quand même...", Clefs pour l'imaginaire ou l'autre scene, Seuil.

Pfaller, Robert

2014 On the Pleasure Principle in Culture. Illusions without Owners, Verso.

Prenter, Regin

1958 Protestantismen i vor tid, Hirschsprungs Forlag.

Sandbeck, Lars

2016 “Slavoj Žižek - en kristen ateist?”, in: Mads Peter Karlsen \& Lars Sandbeck, eds., \& Teologi. Festskrift til Carsten Pallesen, Eksistensen.

Sharpe, Matthew and Boucher, Geoff

2010 Žižek and Politics: A Critical Introduction, Edinburgh University Press.

Žižek, Slavoj

1989 The Sublime Object of Ideology, Verso.

1991 Looking Awry - An Introduction to Jacques Lacan through Popular Culture, MIT Press.

1992 For They do not Know - Enjoyment as a Political Factor, Verson.

1993 Tarrying with the Negative. Kant, Hegel, and Critique of Ideology, Duke University Press.

1994a The Metastases of Enjoyment: Six Essays on Women and Causality, Verso.

1994b “Spectres of Ideology”, in: Slavoj Žižek, ed., Mapping ideology, Verso.

1999 The Ticklish Subject. The absent Centre of Political Ontology, Verso.

2001 On Belief, Routledge.

2002a Did Somebody say Totalitarianism? Five Interventions in the (Mis)Use of a Notion, Verso.

2002b Om Troen, Forlaget Anis.

2002c Det skrøbelige absolut - eller hvorfor er den kristne arv værd at kæmpe for?, Gyldendal.

2003 The Puppet and the Dwarf. The Perverse Core of Christianity, MIT Press.

2006 The Parallax View, MIT Press. 
2007 "Humanism is Not Enough - Interview with Slavoj Žižek", International Journal for Žižek Studies 3 (3), 1-20.

2008a Enjoy Your Symptoms! Jacques Lacan in Hollywood and Out, Routledge.

2008b The Plague of Fantasies, Verso.

2010 Living in the End of Times, Verso.

2012 Less Than Nothing. Hegel and the Shadow of Dialectical Materialism, Verso.

Žižek, Slavoj \& Glyn Daly

2004 Conversations with Žižek, Polity Press.

Žižek, Slavoj, Judith Butler \& Ernesto Laclau

2000 Contingency, Hegemony, Universality. Contemporary Dialogues on the Left, Verso.

Žižek, Slavoj \& John Milbank

2009 The Monstrosity of Christ - Paradox or Dialectic? MIT Press.

Mads Peter Karlsen, adjunkt, ph.d., Department of Management, Politics \& Philosophy, Copenhagen Business School, mpk.mpp@cbs.dk 